This document was prepared in conjunction with work accomplished under Contract No. DE-AC09-96SR18500 with the U. S. Department of Energy.

\title{
DISCLAIMER
}

This report was prepared as an account of work sponsored by an agency of the United States Government. Neither the United States Government nor any agency thereof, nor any of their employees, nor any of their contractors, subcontractors or their employees, makes any warranty, express or implied, or assumes any legal liability or responsibility for the accuracy, completeness, or any third party's use or the results of such use of any information, apparatus, product, or process disclosed, or represents that its use would not infringe privately owned rights. Reference herein to any specific commercial product, process, or service by trade name, trademark, manufacturer, or otherwise, does not necessarily constitute or imply its endorsement, recommendation, or favoring by the United States Government or any agency thereof or its contractors or subcontractors. The views and opinions of authors expressed herein do not necessarily state or reflect those of the United States Government or any agency thereof. 
WSRC-MS-2005-00051

\section{Electrochemical and Antimicrobial Properties of Diamondlike Carbon-Metal Composite Films}

M. L. Morrison ${ }^{1 *}$, R. A. Buchanan ${ }^{1}$, P. K. Liaw ${ }^{1}$, C. J. Berry ${ }^{2}$, R. Brigmon ${ }^{2}$, L. Riester ${ }^{3}$, C. $\operatorname{Jin}^{4}$, R. J. Narayan ${ }^{4}$

1. Department of Materials Science and Engineering, The University of Tennessee, 434 Dougherty Engineering Building, Knoxville, TN 37996-2200, USA

2. Environmental Biotechnology Section, Savannah River National Laboratory, Aiken, SC 29808, USA

3. Metals and Ceramics Division, Oak Ridge National Laboratory, Oak Ridge, TN 37831, USA

4. Interdisciplinary Bioengineering Program and School of Materials Science and Engineering, Georgia Institute of Technology, 771 Ferst Dr NW, Atlanta, GA 30332-0245, USA

*Corresponding Author: Tel - 865.974.5336, Fax - 865.974.4115, E-mail address: mmorrison@utk.edu. 
WSRC-MS-2005-00051

\begin{abstract}
Implants containing antimicrobial metals may reduce morbidity, mortality, and healthcare costs associated with medical device-related infections. We have deposited diamondlike carbonsilver (DLC-Ag), diamondlike carbon-platinum (DLC-Pt), and diamondlike carbon-silverplatinum (DLC-AgPt) thin films using a multicomponent target pulsed laser deposition process. Transmission electron microscopy of the DLC-silver and DLC-platinum composite films revealed that the silver and platinum self-assemble into nanoparticle arrays within the diamondlike carbon matrix. The diamondlike carbon-silver film possesses hardness and Young's modulus values of $37 \mathrm{GPa}$ and $331 \mathrm{GPa}$, respectively. The diamondlike carbon-metal composite films exhibited passive behavior at open-circuit potentials. Low corrosion rates were observed during testing in a phosphate-buffered saline (PBS) electrolyte. In addition, the diamondlike carbon-metal composite films were found to be immune to localized corrosion below $1000 \mathrm{mV}$ (SCE). DLC-silver-platinum films demonstrated exceptional antimicrobial properties against Staphylococcus bacteria. It is believed that a galvanic couple forms between platinum and silver, which accelerates silver ion release and provides more robust antimicrobial activity. Diamondlike carbon-silver-platinum films may provide unique biological functionalities and improved lifetimes for cardiovascular, orthopaedic, biosensor, and implantable microelectromechanical systems.
\end{abstract}

Keywords: Diamondlike carbon, pulsed laser deposition, corrosion 
WSRC-MS-2005-00051

\section{INTRODUCTION}

Medical device infection is associated with significant morbidity, mortality, and associated healthcare costs [1-2]. Microorganisms colonize the medical device surface, and form sessile communities known as a biofilms. These biofilms contain 5-50 $\mu \mathrm{m}$ thick glycoprotein matrices that protect the bacteria through a diffusion limitation process, and increase their resistance to antibodies, macrophages, and antibiotics. In addition, the constituents of stainless steel and cobalt-based alloys can inhibit macrophage chemotaxis, phagocytosis, and other immune system processes for dealing with infection [3]. Finally, tissue damage (e.g., prior irradiation for treatment of malignancy) may increase susceptibility to infection. Local and systemic infections may result, including insertion site abscess, septicemia, endocarditis, and gangrene of extremities. The healthcare costs associated with medical device infections are enormous; for example, systemic bloodstream infections are associated with an estimated cost of $\$ 25,000$ per episode [4].

The sustained delivery of antimicrobial agents into the medical device microenvironment may prevent biofilm formation and avoid systemic side effects associated with oral or intravenous antimicrobial administration [5-6]. For example, coating a medical device with silver may impart antimicrobial and anti-inflammatory properties. Silver has been used in medicine since the late nineteenth century, when Crede introduced 1\% silver nitrate solution for preventing ocular infections in neonates [7]. Silver has several effects on microbial cells, including impeding the cytochrome respiratory chain, impeding the microbial electron transport system, and preventing DNA replication [8-10]. Silver is effective against a broad range of yeast, fungi, viruses, aerobic bacteria, anaerobic bacteria, Gram-negative bacteria (including Pseudomonas aeruginosa), and Gram-positive bacteria (including methicillin-resistant 
Staphylococcus aureus) [11-14]. Silver may also possess anti-inflammatory properties; for example, studies have shown increased neutrophil apoptosis, reduced matrix metalloproteinase activity, reduced tumor necrosis factor-alpha levels, and more rapid healing in wounds dressed with silver [15-19]. Silver must be in a soluble, uncharged $\left(\mathrm{Ag}^{0}\right)$ or metallic $\left(\mathrm{Ag}^{+1}\right)$ form to provide these biological effects [7]. Silver nitrate, silver sulfadiazine, and nanocrystalline silver are FDA-approved antimicrobials that are used in the treatment of chronic wounds. Conventional ionic silver preparations, such as silver nitrate and silver sulfadiazine, are quickly inactivated in biological fluids because silver chloride and other biologically inactive complexes are formed. As a result, larger quantities of these preparations must be continually reapplied to provide antimicrobial activity. It is currently believed that nanocrystalline silver is far less rapidly deactivated by biological fluids than the ionic form, and can provide sustained antimicrobial action in medical applications. Nanocrystalline silver dissolves in biological solutions to provide a concentration of $\mathrm{Ag}^{0}$ and $\mathrm{Ag}^{+1}$ ions in the range of $\sim 70 \mathrm{ppm}$ [20-23]. As the silver ions are depleted, an equilibrium shift causes additional $\mathrm{Ag}^{0}$ and $\mathrm{Ag}^{+1}$ ions to be released. Several groups have demonstrated that galvanically coupling silver with platinum can further increase antimicrobial activity by accelerating the silver ion release [24]. Devices containing nanocrystalline silver and platinum may provide improved antimicrobial and antiinflammatory properties for implantable medical devices.

We have incorporated silver and platinum within diamondlike carbon (DLC) thin films in order to provide these otherwise inert medical-device coatings with antimicrobial properties. The term diamondlike carbon is used to describe hydrogen-free carbon solids that contain an amorphous network of tetrahedrally and trigonally hybridized carbon atoms [25]. Diamondlike carbon thin films demonstrate inert behavior with many human cells; for example, in vitro 
studies involving kidney 293 cells, myeloblastic ML-1 cells, and osteoblast-like cells have demonstrated that diamondlike carbon films do not elicit an inflammatory response [26-30]. These materials can also impart wear resistance, hardness, and corrosion resistance to a medical device surface, and have been considered for use in a variety of cardiovascular, orthopaedic, biosensor, and implantable microelectromechanical system devices. For example, diamondlike carbon has been considered for use in a coronary artery stents, synthetic heart valves, left ventricular assist devices, and artificial hearts, because platelet activation and platelet adhesion occur less often on diamondlike carbon-coated surfaces than on conventional (titanium, titanium carbide, titanium nitride, or stainless steel) surfaces [31-38]. Another medical application for diamondlike carbon thin films is use on hip joint prostheses and knee joint prostheses. Diamondlike carbon is an ideal surface coating for prosthetic joints, because it is wear resistant, atomically smooth, and corrosion resistant, has a low friction coefficient, and is immune to scratching by third body wear particles [39-43]. For example, Tiainen et al. demonstrated that the amount of wear in DLC-coated metal/DLC-coated metal wear couples was $10^{5}-10^{6}$ times lower than in conventional metal/polyethylene and metal/metal wear couples [44]. The corrosion properties of DLC-coated metals are also outstanding; Tiainen et al. have shown that DLC-coated cobalt-chromium-molybdenum alloy provides a $10^{5}$ lower corrosion rate than uncoated cobalt-chromium-molybdenum alloy [45]. Implantable mechanical microelectromechanical systems (MEMS) and implantable robots also require extremely wear resistant surfaces, because the friction-force term in movement equations decreases as the second power of the scale, but the inertia term decreases as the third power of the scale. DLC exhibits wear resistance up to 10,000 times greater than polysilicon [46]. In addition, low surface energies (40-44 $\mathrm{mN} \mathrm{m}^{-1}$ ) and large contact angles (75-80 ${ }^{\circ}$ with water) are typically observed in 
DLC films [47, 48]. These properties could dramatically extend the lifetimes of new generation implantable microdevices.

Diamondlike carbon-silver (DLC-Ag), diamondlike carbon-platinum (DLC-Pt), and diamondlike carbon-silver-platinum (DLC-AgPt) thin films were prepared using a rotating multicomponent target pulsed laser deposition process. These films were examined using transmission electron microscopy, visible Raman spectroscopy, and nanoindentation. Electrochemical testing was conducted to assess the general and localized corrosion resistance of these materials. Microbial biofilm attachment testing was performed using gram positive Staphylococcus bacteria. Diamondlike carbon-silver-platinum films may provide unique biological functionalities and improved lifetimes for next generation cardiovascular, orthopaedic, biosensor, and implantable microelectromechanical systems.

\section{EXPERIMENTAL METHODS}

Several $1 \mathrm{~cm}$ x $1 \mathrm{~cm}$ pieces of silicon (100) were cleaned in acetone and methanol within an ultrasonic cleaner. The silicon substrates were subsequently dipped in hydrofluoric acid to remove silicon oxide, which resulted in a hydrogen-terminated surface. In addition, several $2 \mathrm{~cm}$ x $2 \mathrm{~cm}$ Ti-6Al-4V (wt.\%) pieces, denoted as Ti-Al-V, were cleaned in acetone and methanol. The cleaned substrates and target were loaded into a pulsed laser deposition chamber, which was evacuated to a pressure of $\sim 5 \times 10^{-6}$ Torr (Figure 1). A Lambda Physik LPX $200 \mathrm{KrF}$ excimer laser $(\lambda=248 \mathrm{~nm})$ was used for ablation of the multicomponent target. The laser was operated at a frequency of $10 \mathrm{~Hz}$ and a pulse duration of $25 \mathrm{~ns}$. The laser energy output of $215 \mathrm{~mJ}$ and a laser spot size of $0.04 \mathrm{~cm}^{2}$ imparted an average energy density of $\sim 5 \mathrm{~J} / \mathrm{cm}^{2}$ to the target. The multicomponent target was rotated at a rate of 5 RPM throughout the deposition process. The multicomponent target was created by placing pieces of silver and/or platinum over the graphite 
target; approximately $90^{\circ}$ of the ablation circle was covered by each metal piece (Figure 2). The target-substrate distance was maintained at $4.5 \mathrm{~cm}$.

High-resolution Z-contrast images were obtained using a JEOL 2010 F scanning transmission electron microscope (STEM) equipped with field emission gun and Gatan Image Filter (GIF). In STEM-Z contrast imaging, an image is formed by collecting large-angle scattered electrons using an annular detector. The resulting contrast is proportional to the atomic number squared $\left(\mathrm{Z}^{2}\right)$. Raman spectra of the diamondlike carbon layer were obtained using a SPEX 1704 spectrometer with argon ion laser source $(\lambda=514.5 \mathrm{~nm})$ (Horiba Jobin Yvon Inc., Edison NJ). Peak positions were obtained from Gaussian interpolation of the Raman data.

A Nanoindenter II ${ }^{\circledR}$ system (MTS Instruments, Oak Ridge TN) was used to determine nanohardness and Young's modulus values for the diamondlike carbon and diamondlike carbonsilver films. The samples were examined using an ultra-low load DCM indentation head and a three-sided diamond pyramid (Berkovitch) tip. Indentations were performed using a trapezoidal loading curve. The maximum load was varied between 150 and $600 \mathrm{mN}$. A constant loading rate of $30 \mathrm{mN} / \mathrm{s}$ was applied. Nanohardness and Young's modulus values were measured as a function of indentation depth, and were determined using a modified Oliver-Pharr model [49]. The tip was calibrated following the partial unloading method, and was cleaned with isopropanol between indentations.

Electrochemical cyclic-anodic-polarization tests were conducted using an EG\&G Princeton Applied Research 263A potentiostat with Powercorr software (Princeton Applied Research, Oak Ridge, TN). The electrochemical cell consisted of the corrosion sample, a saturated calomel reference electrode, and a platinum counter electrode. Thus, all potentials were described in reference to the saturated calomel electrode (SCE). Electrochemical 
characterization was performed in a phosphate-buffered saline (PBS) electrolyte at $37^{\circ} \mathrm{C}$. The composition of the electrolyte is presented in Table 1. These studies were performed on seven diamondlike carbon-silver, diamondlike carbon-platinum, and diamondlike carbon-silverplatinum films deposited on Ti-Al-V substrates. A control group of six Ti-Al-V substrates was also examined. Each of the DLC-coated samples was subjected to corrosion testing only one time, because the DLC-metal composite films were of insufficient thickness for multiple tests.

The PBS electrolyte is meant to simulate in vivo electrochemical conditions. The mean $\mathrm{pH}$ ( $\pm 95 \%$ confidence intervals) of the PBS electrolyte for all tests was $7.41 \pm 0.01$, which is near that found in the human body $(7.0$ - 7.4) [50]. The dissolved oxygen content of this electrolyte was reduced to a physiologically-relevant value of $3.3 \times 10^{-2} \mathrm{~mol} / \mathrm{m}^{3}$ by aerating the electrolyte with a $4 \% \mathrm{O}_{2} / \mathrm{N}_{2}$ gas mixture at a flow rate of $50 \mathrm{~mL} / \mathrm{min}$ for one hour prior to testing [51]. Aeration was continued throughout corrosion testing in order to maintain the reduced oxygen content.

A polymer sample holder was used to repeatedly expose $28 \mathrm{~mm}^{2}$ of each sample to the electrolyte during testing. Before each polarization scan was initiated, the corrosion sample was allowed to stabilize in the electrolyte until the potential changed by no more than $2 \mathrm{mV}$ over a five minute time period. This value was determined to be the open-circuit corrosion potential ( $\left.\mathrm{E}_{\text {corr }}\right)$. The potential scan was started at $20 \mathrm{mV}$ below $\mathrm{E}_{\text {corr }}$ and continued in a positive direction at a scan rate of $0.17 \mathrm{mV} / \mathrm{s}$ until a potential of $1000 \mathrm{mV}$ (SCE) was reached. At this point, the scan direction was reversed, and the potential was decreased at the same rate until a new $\mathrm{E}_{\text {corr }}$ was reached. A vertex potential of $1000 \mathrm{mV}$ (SCE) was selected as a conservative, maximum potential for investigation for the following reasons. Assuming that the dissolved oxygen is the principal oxidizer (cathodic reagent) in the biocorrosion process at near-neutral $\mathrm{pH}$ values, $\mathrm{E}_{\text {corr }}$ 
could not be above the equilibrium potential for the half-cell reaction, $\mathrm{O}_{2}+2 \mathrm{H}_{2} \mathrm{O}+4 \mathrm{e}=4 \mathrm{OH}^{-}$, which is $549 \mathrm{mV}$ (SCE) at $\mathrm{pH}=7.4$. These equilibrium potentials are given by "line b" on potential-pH Pourbaix diagrams [52] for an oxygen partial pressure of one atmosphere. Considering that the partial pressure of oxygen in the PBS electrolyte was much lower than this, giving even lower potentials, a $1000 \mathrm{mV}$ (SCE) vertex potential provides a potential range that encompasses all possible $\mathrm{E}_{\text {corr }}$ values, even with additional oxidizers present.

Following electrochemical testing, several corrosion-related parameters were derived from the cyclic-anodic-polarization curves [53]. The cyclic-anodic polarization test provides information on the localized corrosion resistance and the general corrosion rate of a given material in the test environment. The controlled specimen potential can be regarded as the “driving force” for corrosion, and the anodic current density is directly related to the specimen corrosion rate. All of the materials were found to be immune to localized corrosion in the tested environment; therefore, only the corrosion-penetration rates and the passive anodic current densities will be discussed.

The open-circuit corrosion-current density ( $\left.\mathrm{i}_{\text {corr }}\right)$ and corrosion-penetration rate (CPR) are directly related to the total amount of the metal content introduced into the body as described by the Taylor equation $[54,55]$. The CPR is an estimate of the corrosion rate of a material at $\mathrm{E}_{\text {corr }}$. This value is dependent on inherent material and electrolyte properties and can be determined from $\mathrm{i}_{\text {corr }}$ by the application of Faraday's Law [56]. In this study, $\mathrm{i}_{\text {corr }}$ was calculated by the polarization-resistance method. It is important to note that the values derived from electrochemical tests are dependent on the potential scan rate and other test variables.

Statistical analyses of the corrosion data were performed using JMP 5.1.1 software (SAS Institute Inc., Cary, NC). The parametric assumptions of equal variance and residual normality 
were tested for the derived corrosion parameters. These assumptions were not valid for the $\mathrm{E}_{\text {corr }}$ and CPR data, and the Box-Cox transformation [57] was used in an attempt to improve the compliance with the parametric assumptions. For the $\mathrm{E}_{\text {corr }}$ data, these assumptions were not met even after using the Box-Cox transformation, and the nonparametric Kruskal-Wallis test with pairwise comparisons was utilized instead to provide statistically-relevant data [58]. In the case of the CPR values, the Box-Cox transformation $(\lambda=0.1)$ normalized the residuals $(p=0.2110)$, but did not improve the equality of the variances. In this case, the Welch analysis of variance (ANOVA) test [59], which does not assume equality of variances, and Tukey's post-hoc tests were used on the transformed corrosion-penetration rate data. Finally, 95\% confidence interval (CI) values were calculated for all of the means presented in this study, based on the Student's tdistribution.

Biofilm attachment studies were performed with wild type Staphylococcus sp grown in liquid media. Organisms were grown in a nutrient broth solution, which was prepared by dissolving 8 g nutrient broth powder (Difco, Detroit, MI) in one liter of sterilized water. The inoculated broth was heated to $37^{\circ} \mathrm{C}$ for 15 minutes on a shaker platform; the solution was maintained under $100 \mathrm{kPa}$ pressure during this time. When log phase growth was obtained, $1 \mathrm{~cm}$ x 1cm pieces of DLC-silver/silicon, DLC-silver-platinum/silicon, and silicon (control) were rinsed with ethyl alcohol; aseptically added to the media; and incubated for 24, 48 and 72 hours. Incubated materials were rinsed three times in an FA buffer solution, which was prepared by dissolving 10 g FA buffer powder (Difco, Detroit, MI) in one liter of deionized, ultrafiltered water. The incubated materials were then vortexed for one minute, and rinsed an additional two times in FA buffer solution. Samples were then heat fixed at $60^{\circ} \mathrm{C}$ for 12 minutes, stained for five minutes with 4'-6-Diamidino-2-phenylindole dihydrochloride (DAPI) (0.7 micrograms of 
DAPI (Sigma Chemical Co., St. Louis, MO) per ml of phosphate buffer, $\mathrm{pH}$ 7.5), and rinsed with the FA buffer. Stained microbial cells were examined using a Axioskop2 Plus epifluorescent microscope (Carl Zeiss Inc., Thornwood, NY) and a 510 Meta laser scanning microscope (Carl Zeiss Inc., Thornwood, NY) using appropriate filter sets.

\section{RESULTS AND DISCUSSION}

\subsection{Z-contrast scanning transmission electron microscopy}

Z-contrast scanning transmission electron microscopy provides unique structural information on nanocomposite thin films [60]. The Z-contrast image is formed by scanning a 2.2 $\AA$ probe across an ion implantation-thinned region of the film. The Z-contrast signal is collected using a high-angle annular detector, and the electron signal scattered through large angles (typically 75 to $150 \mathrm{mrad}$ ) is analyzed. The resulting contrast is proportional to the atomic number squared $\left(Z^{2}\right)$. For example, the silver: carbon contrast is over $60: 1$, and the platinum:carbon contrast is 169:1. Dark field Z-contrast images of the diamondlike carbonsilver and the diamondlike carbon-platinum composite films are shown in Figures 3 and 4, respectively. The dark regions correspond to the higher atomic number metal regions, and the bright regions correspond to the DLC matrix. The average size of these nanocrystalline particles varied between $3 \mathrm{~nm}$ and $5 \mathrm{~nm}$. These images demonstrate that the noble metals are segregated into nanoparticle arrays within the diamondlike carbon matrix. These nanoparticle arrays may serve as reservoirs for neutral-metal and metal-ion species when placed within in vitro and in vivo environments.

\subsection{Raman spectroscopy}

The Raman spectra of the diamondlike carbon films (Figure 5) contain two prominent features. A broad hump centered at $1510-1557 \mathrm{~cm}^{-1}$ is referred to as the G-band; this feature 
reflects the optically allowed $E_{2 g}$ zone center mode of crystalline graphite. A small shoulder at $1350 \mathrm{~cm}^{-1}$ is the $\mathrm{A}_{1 \mathrm{~g}}$ disorder-allowed zone edge mode of graphite, and is called the D-band. Both diamondlike carbon-silver and diamondlike carbon-platinum composite films contain the following features: the G-band exhibits a reduction in peak width (FWHM), the G-band exhibits a shift to lower wavenumbers, and the D-band increases in size. These features were observed in both diamondlike carbon-silver and diamondlike carbon-platinum films. The G band position shift can be related a decrease in $\mathrm{sp}^{3}$ content or an increase in graphitic cluster size [61-62]. The reduction of G-band width can also be attributed to a decrease in compressive stresses within the film. The increase in D-band height appears to be inversely correlated with the amount of $\mathrm{sp}^{3}$ hybridized carbon atoms (Figure 5). These features taken together suggest that diamondlike carbon-silver and diamondlike carbon-platinum composite films possess lower amounts of tetrahedrally hybridized atoms and/or a decrease in compressive stresses within the film.

\subsection{Nanoindentation}

During nanoindentation, the modulus of the coated sample approached that of the uncoated sample at approximately $600 \mathrm{~nm}$. The mean ( \pm standard deviation) nanohardness and Young's modulus values for the diamondlike carbon-silver composite film were determined to be $37.4 \pm 6.7 \mathrm{GPa}$ and $331.0 \pm 40.8 \mathrm{GPa}$, respectively (Table 2). These values are similar to those observed in layered WC/DLC and TiC/DLC composites prepared using magnetron sputtering or electron cyclotron resonance chemical vapor deposition techniques (nanohardness 27 GPa). In addition, these values are significantly greater than those observed in a-C:H-copper coatings prepared using plasma-enhanced chemical vapor deposition (PECVD) or hybrid microwave plasma-assisted chemical vapor deposition/sputtering techniques (nanohardness 10 GPa) [63-67]. 
WSRC-MS-2005-00051

\subsection{Electrochemical characterization}

The average cyclic-anodic-polarization curve for each of the materials is shown in Figure 6. These curves demonstrate that each material was passive at $E_{\text {corr }}$ and exhibited low opencircuit corrosion current densities $\left(0.08-0.39 \mathrm{~mA} / \mathrm{m}^{2}\right)$ in the passive region. The $\mathrm{E}_{\text {corr }}$ values are plotted for comparison in Figure 7. The Ti-Al-V substrate demonstrated a low mean $( \pm 95 \%$ CIs) CPR of $0.1 \pm 0.0 \mu \mathrm{m} /$ year (Figure 8 ). The mean ( $\pm 95 \%$ CIs) CPR values were determined to be $0.2 \pm 0.1,0.2 \pm 0.2$, and $0.3 \pm 0.1 \mu \mathrm{m} /$ year for the diamondlike carbon-silver, diamondlike carbon-platinum, and diamondlike carbon-silver-platinum films, respectively. All of these values were exceptionally low and within the expected range of behavior of corrosion-resistant passive materials. In addition, all of the materials examined in this study were found to be immune to localized corrosion below $1000 \mathrm{mV}$ (SCE).

Several of the relevant corrosion parameters from this study are compared with literature values in Table 3. Some of the corrosion values in this table were calculated or estimated from analysis of the polarization curves found in published data. Morrison et al. [68] evaluated the corrosion resistance of several medical-grade biomaterials, including Ti-Al-V (ASTM F136), CoCrMo (ASTM F799), and AISI 316L stainless steel (ASTM F138), following identical testing procedures in PBS electrolyte solution. The mean ( $\pm 95 \%$ confidence intervals) CPR values were reported to be $0.3 \pm 0.2,0.3 \pm 0.2$, and $1.5 \pm 0.4$ for Ti-Al-V, CoCrMo, and 316L SS, respectively. These values are also plotted in Figure 8 for comparison. Ti-Al-V, diamondlike carbon-silver, diamondlike carbon-platinum, and diamondlike carbon-silver-platinum films exhibited statistically significant 93\%, 87\%, 87\%, and $80 \%$ lower CPR values than 316L SS (p < 0.0001), respectively. All other variations among CPR values were not found to be statistically significant. The immunity to localized corrosion observed in diamondlike carbon-silver, 
WSRC-MS-2005-00051

diamondlike carbon-platinum, and diamondlike carbon-silver-platinum films was comparable to that observed in Ti-Al-V and CoCrMo alloys.

\subsection{Antimicrobial testing}

The gram positive Staphylococcus sp produced quantifiable biofilms after 24, 48, and 72 hours. The amount of microbial colonization varied with incubation period and composite film type; a significant variation in the amount of microbial colonization per unit area was observed among uncoated silicon (100) substrates, diamondlike carbon-silver films, and diamondlike carbon-silver-platinum films. The silicon substrate used as a control demonstrated planktonic and biofilm-forming clusters after incubation with Staphylococcus sp (Figure 9). On the other hand, the diamondlike carbon-silver and diamondlike carbon-silver-platinum films demonstrated significantly lower microbial concentrations over all time scales. At 72 hours testing, the diamondlike carbon-silver film demonstrated greater than fifty percent lower colonization rate than the uncoated silicon substrate, and the diamondlike carbon-silver-platinum composite film demonstrated a ninety percent lower colonization rate than the uncoated silicon substrate. These results suggest that the galvanic couple between silver and platinum accelerates silver ion release and provides additional antimicrobial functionality to the film surface.

\section{CONCLUSIONS}

Diamondlike carbon-silver, diamondlike carbon-platinum, and diamondlike carbonsilver-platinum composite films were prepared using a novel multicomponent target pulsed laser deposition process. Silver and platinum form nanoparticle arrays within the diamondlike carbon matrix. This nanoparticle composite structure can be attributed to the high surface energy of noble metals relative to carbon. Ostwald ripening is prevented, and the resulting metal nanoparticles possess uniform sizes. Diamondlike carbon-silver composite films possess 
sufficient hardness and Young's modulus values for most medical applications; these values observed were between those of diamondlike carbon and those of refractory nitrides. The diamondlike carbon-metal composite films exhibited passive behavior at the open-circuit potentials, and low corrosion rates in the phosphate-buffered saline (PBS) electrolyte. No statistically significant differences were observed between the corrosion-penetration rates of the diamondlike carbon-silver composite film, diamondlike carbon-platinum composite film, and the diamondlike carbon-silver-platinum composite film. All of these films were found to be immune to localized corrosion below $1000 \mathrm{mV}$ (SCE). Finally, diamondlike carbon-silver-platinum composites exhibit significant antimicrobial efficacy against Staphylococcus bacteria. Robust antimicrobial function was observed in diamondlike carbon-silver-platinum composite films; this functionality is attributed to the formation of a galvanic couple between silver and platinum that enhances silver ion release. Diamondlike carbon-metal composite films may provide higher hardness, corrosion resistance, and antimicrobial functionalities to next generation cardiovascular, orthopaedic, biosensor, and MEMS devices.

\section{ACKNOWLEDGEMENTS}

The authors are grateful to the National Science Foundation Integrative Graduate Education and Research Training (IGERT) Program on Materials Lifetime Science and Engineering, managed by Drs. L. Clesceri, W. Jennings, and L. Goldberg, and the Office of Naval Research Young Investigator Program for the support of this research. 


\section{REFERENCES}

1. W. R. Jarvis, Infect. Cont. Hosp. Ep. 17 (1996) 552.

2. W. E. Stamm, Ann. Int. Med. 89 (1978) 764.

3. N. J. Hallab, A. Skipor, J. J. Jacobs, J. Biomed. Mater. Res. A 65 (2003) 311.

4. R. O. Darouiche, Clin. Infect. Dis. 29 (1999) 1371.

5. D. J. Stickler, Curr. Opin. Infect. Dis. 13 (2000) 389.

6. J.M. Schierholz, L.J. Lucas, A. Rump and G. Pulverer, J. Hosp. Infect. 40 (1998) 247.

7. K. Dunn, V. Edwards-Jones, Burns 30 (2004) S1.

8. P. D. Bragg, D. J. Rainnie, Can. J. Microbiol. 20 (1974) 883.

9. M S. Modak, C. L. Fox, Biochem. Pharmacol. 22 (1973) 2391.

10. H. S. Rosenkranz, S. Rosenkranz, Antimicrob. Agents Chemother. 2 (1972) 373.

11. P. K. Stoimenov, R. L. Klinger, G. L. Marchin, K. J. Klabunde, Langmuir 18 (2002) 6679.

12. R. M. Slawson, M. I. Van Dyke, H. Lee, J. T. Trevors, Plasmid 27 (1992) 72.

13. G. J. Zhao, S. E. Stevens, Biometals 11 (1998) 27.

14. J. A. Spadaro, T. J. Berger, S. D. Barranco, S. E. Chapin, R. O. Becker, Microb. Agents Chemother. 6 (1974) 637.

15. N. J. Trengove, M. C. Stacey, S. Macaulley, N. Bennett, J. Gibson, F. Burslem, G. Murphy, G. Schultz, Wound Rep. Regen. 7 (1999) 442.

16. A. A. Rogers, S. Burnett, I. C. Moore, P. G. Shakespeare, W. Y. J. Chen, Wound Rep. Regen. 3 (1995) 273.

17. J. B. Wright, K. Lam, A. G. Buret, M. E. Olson, R. E. Burrell, Wound Rep. Reg. 10 (2002) 141.

18. R. H. Demling, L. DeSanti, Burns 28 (2002) 264. 
19. M. E. Olson, J. B. Wright, K. Lam, R. E. Burrell, Eur. J. Surg. 166 (2000) 486.

20. C. R. Ricketts, E. J. Lowbury, J. C. Lawrence, M. Hall, M. D. Wilkins, Br. Med. J. 1 (1970) 444.

21. P. Spacciapoli, D. Buxton, D. Rothstein, P. Friden, I. Periodontal Res. 36 (2001) 108.

22. R. E. Hall, G. Bender, R. E. Marquis, J. Oral Maxillofac. Surg. 45 (1987) 779.

23. P. A. Maple, J. M. Hamilton-Miller, W. Brumfitt, Antimicrob. Chemother. 29 (1992) 661.

24. D. P. Dowling, A. J. Betts, C. Pope, M. L. McConnell, R. Eloy, M. N. Arnaud, Surf. Coatings Technol. 163-164 (2003) 637.

25. Q. Wei, J. Sankar, A.K. Sharma, S. Oktyabrsky, J. Narayan, R.J. Narayan, J. Mater. Res. 15 (2000) 633.

26. M. Allen, B. Myer, N. Rushton, J. Biomed. Mater. Res. B 58 (2001) 319.

27. M. Allen, F. Law, N. Rushton, Clin. Mater. 17 (1994) 1.

28. S. Linder, W. Pinkowski, M. Aepfelbacher, Biomaterials 23 (2002) 767.

29. E. Liu, B. Blanpain, J. P. Celis, J. R. Roos, G. Alvarezverven, T. Priem, Surface Coatings Technol. 80 (1996) 264.

30. L. A. Thomson, F. C. Law, N. Rushton, J. Franks, Biomaterials 12 (1991) 37.

31. H. S. Tran, M. M. Puc, C. W. Hewitt, D. B. Soll, S. W. Marra, V. A. Simonetti, J. H. Cilley, A. J. Delrossi, J. Invest. Surg. 12 (1999) 133.

32. I. De Scheerder, M. Szilard, Y. M. Huang, X. B. Ping, E. Verbeken, D. Neerinck, E. Demeyere, W. Coppens, F. van de Werf, J. Invasive Cardiology 12 (2000) 389.

33. K. Gutensohn, C. Beythien, J. Bau, T. Fenner, P. Grewe, R. Koester, K. Padmanaban, P. Kuehnl, Thrombosis Res. 99 (2000) 577. 
34. M. I. Jones, I. R. McColl, D. M. Grant, K. G. Parker, T. L. Parker, J. Biomed. Mater. Res. 52 (2000) 413.

35. G. F. Yin, J. M. Luo, C. Q. Zheng, H. H. Tong, Y. F. Huo, L. L. Mu, Thin Solid Films 345 (1999) 67.

36. L. J. Yu, X. Wang, X. H. Wang, X. H. Liu, Surface Coatings Technol., 2000, 128, 484-488.

37. A. Alanazi, C. Nojiri, T. Kido, T. Noguchi, Y. Ohgoe, T. Matsuda, K. Hirakuri, A. Funakubo, K. Sakai, Y. Fukui, Artif. Organs, 2000, 24, 624-627.

38. K. Yamazaki, P. Litwak, O. Tagusari, T. Mori, K. Kono, M. Kameneva, M. Watach, L. Gordon, M. Miyagishima, J. Tomioka, M. Umezu, E. Outa, J. F. Antaki, R. L. Kormos, H. Koyanagi, B. P. Griffith, Artif. Organs, 1998, 22, 466-474.

39. S. Santavirta, Y. T. Konttinen, R. Lappalainen, A. Anttila, S. B. Goodman, M. Lind, L. Smith, M. Takagi, E. Gomez-Barrena, L. Nordsletten, J. W. Xu, Curr. Orthop. 12 (1998) 5157.

40. P. F. Doorn, P. A. Campbell, H. C. Amstutz, Clin. Orthop. 329 (1996) 206.

41. S. B. Goodman, V. L. Fornasier, J. Lee, J. Kei, J. Biomed. Mater. Res. 24 (1990) 517.

42. L. C. Jones, D. S. Hungerford, Clin. Orthop. 225 (1987) 192.

43. S. Santavirta, Y. T. Konttinen, V. Bergroth, M. Gronblad, Acta Orthop. Scand. 62 (1991) 29.

44. V. M. Tiainen, Diamond Related Mater. 10 (2001) 153.

45. J. Franks, J. Vac. Sci. Technol. A. 7 (1989) 2307.

46. J. P. Sullivan, T. A. Friedmann, K. Hjort, MRS Bull. 26 (2001) 309.

47. M. Grischke, K. Bewilogua, K. Trojan, H. Dimigen, Surf. Coatings Technol. 74-75 (1996) 739.

48. H. Han, F. Ryan, M. McClure, Surface Coatings Technol. 121 (1999) 579. 
49. T. A. Friedmann, J. P. Sullivan, J. A. Knapp, D. R. Tallant, D. M. Follstaedt, D. L. Medlin, P. B. Mirkarimi, Appl. Phys. Lett. 71 (1997) 3820.

50. S. Hiromoto, A. P. Tsai, M. Sumita, T. Hanawa, Mater Trans 42 (2001) 656.

51. S. Hiromoto, K. Asami, A. P. Tasi, M. Sumita, T. Hanawa, J. Electrochem. Soc. 149 (2002) B117.

52. M. Pourbaix, Atlas of Electrochemical Equilibria in Aqueous Solutions, National Association of Corrosion Engineers, Houston, 1974.

53. W. H. Peter, R. A. Buchanan, C. T. Liu, P. K. Liaw, M. L. Morrison, J. A. Horton, C. A. Carmichael, J. L. Wright, Intermetallics 10 (2002) 1157.

54. D. M. Taylor, J. Bone Joint Surg. B 55 (1973) 422.

55. K. J. Bundy, R. Luedemann, Ann. Biomed. Mater. 17 (1989) 159.

56. E. E. Stansbury, R.A. Buchanan, Fundamentals of Electrochemical Corrosion, ASM International, Materials Park, OH, 2000.

57. G. E. P. Box, D.R. Cox, J. Royal. Stat. Soc. B 26 (1964) 211.

58. A. C. Tamhane, D. D. Dunlop, Statistics and Data Analysis, Prentice Hall, Upper Saddle River, NJ, 2000.

59. B.L. Welch, Biometrika 38 (1951) 330.

60. D. Kumar, S. J. Pennycook, A. Lupini, G. Duscher, A. Tiwari, J. Narayan, Applied Physics Letters 81 (2002) 4204.

61. B. K. Tay, P. Zhang, Thin Solid Films 420-421 (2002) 177.

62. V. V. Uglova, V. M. Anishchik, Y. Pauleau, A. K. Kuleshov, F. Thièry, J. Pelletier, S. N. Dub, D. P. Rusalsky, Vacuum 70 (2003) 181.

63. Y. Pauleau, E. Thiery, Surf. Coatings Technol. 181 (2004) 313. 
64. D. Sheeja, B. K. Tay, J. Y. Sze, L. J. Yu, S. P. Lau, Diamond Related Mater. 12 (2003) 2032.

65. H. Rusli, S. F. Yoon, Q. F. Huang, J. Ahn, Q. Zhang, H. Yang, Y. S. Wu, E. J. Teo, T. Osipowicz, F. Watt, Diamond Related Mater. 10 (2001) 132.

66. H. Rusli, S. F. Yoon, H. Yang, J. Ahn, Q. F. Huang, Q. Zhang, Y. P. Guo, C. Y. Yang, E. J. Teo, A. T. S. Wee, A. C. H. Huan, F. Watt, Surf. Coatings Technol. 123 (2000) 134.

67. C. Strondl, N. M. Carvalho, J. T. M. De Hosson, G. J. van der Kolk, Surf. Coatings Technol. 162 (2003) 288.

68. M. L. Morrison, R. A. Buchanan, R. V. Leon, C. T. Liu, B. A. Green, P. K. Liaw, J. A. Horton, J. Biomed. Mater. Res. A (2005) In press.

69. M.A.S. Oliveira, A.K. Vieira and M. Massi, Diam Relat Mater 12 (2003) 2136.

70. M. A. S. Oliveira, M. Massi, L. N. Nishioka, G. P. Thim, R. W. Bartar, A. K. Vieira, J. New Mater. Electrochem. Systems 5 (2002) 67.

71. C. Srividya, I. Moskowitz and S.V. Babu, J Mater Res 14 (1999) 2124.

72. H.P. Feng, C.H. Hsu, J.K. Lu, Y.H. Shy, Mater. Sci. Eng. A 347 (2003) 123.

73. A. Dorner, B. Wielage, C. Schurer, Thin Solid Films 355-356 (1999) 214.

74. A. Dorner-Reisel, C. Schurer, G. Irmer, E. Muller, Surf. Coatings Technol. 177-178 (2004) 830. 
WSRC-MS-2005-00051

\section{LIST OF FIGURES}

Figure 1. Pulsed laser deposition process. Pulsed laser deposition of diamondlike carbon involves laser ablation of a $\mathrm{sp}^{2}$ - hybridized carbon target, which results in the formation of a $\mathrm{sp}^{3}$ - and $\mathrm{sp}^{2}$ - hybridized amorphous carbon film

Figure 2. Rotating multicomponent target design and resulting film nanostructure.

Figure 3. Bright-field transmission electron micrograph of a diamondlike carbon-silver composite film. Silver nanoparticles self-assemble into arrays (dark regions) within the diamondlike carbon matrix (light regions).

Figure 4. Bright-field transmission electron micrograph of a diamondlike carbon-platinum composite film. Platinum nanoparticles self-assemble into arrays (dark regions) within the diamondlike carbon matrix (light regions).

Figure 5. Visible Raman spectra for (a) diamondlike carbon, (b) diamondlike carbon-silver, and (c) diamondlike carbon-platinum films. As the metal concentration is increased, the G-band exhibits a reduction in peak width (FWHM), the G-band exhibits a shift to lower wavenumbers, and the D-band increases in size. These features suggest that the diamondlike carbon-metal composite films contain fewer tetrahedrally bonded carbon atoms than the unalloyed diamondlike carbon films.

Figure 6. The average cyclic-anodic-polarization curves for the Ti-Al-V substrate, diamondlike carbon-silver (DLC-Ag) film on Ti-Al-V substrate, diamondlike carbonplatinum (DLC-Pt) film on Ti-Al-V substrate, and diamondlike carbon-silver-platinum (DLC-AgPt) film on Ti-Al-V substrate.

Figure 7. Mean open-circuit corrosion potentials $\left(\mathrm{E}_{\mathrm{corr}}\right)$ derived from the cyclic-anodicpolarization tests for the Ti-Al-V substrate, diamondlike carbon-silver (DLC-Ag) film 
WSRC-MS-2005-00051

on Ti-Al-V substrate, diamondlike carbon-platinum (DLC-Pt) film on Ti-Al-V substrate, and diamondlike carbon-silver-platinum (DLC-AgPt) film on Ti-Al-V substrate. Literature values for Ti-Al-V, CoCrMo, and AISI 316L stainless steel medical-grade alloys are included for comparison. Error bars represent 95\% confidence intervals.

Figure 8. The mean corrosion-penetration rates (CPRs) for the Ti-Al-V substrate, diamondlike carbon-silver (DLC-Ag) film on Ti-Al-V substrate, diamondlike carbonplatinum (DLC-Pt) film on Ti-Al-V substrate, and diamondlike carbon-silver-platinum (DLC-AgPt) film on Ti-Al-V substrate. Literature values for Ti-Al-V, CoCrMo, and AISI 316L stainless steel medical-grade alloys are included for comparison. Error bars represent 95\% confidence intervals.

Figure 9. Images of Staphylococcus sp. on the surface of a diamondlike carbon-silver film taken using a LSM meta system. Both (a) biofilm-forming clusters and (b) freestanding plankonic bacteria were observed. The diamondlike carbon-silver film demonstrated greater than 50 percent lower colonization rate than the uncoated silicon substrate, and the diamondlike carbon-silver-platinum composite film demonstrated a 90 percent lower colonization rate than the uncoated silicon substrate. 
Table 1. Mechanical properties of diamondlike carbon-metal composite films. Error ranges signify standard deviation values.

\begin{tabular}{lcc}
\hline \multicolumn{1}{c}{ Material } & Hardness (GPa) & Young's modulus (GPa) \\
\hline DLC/Si (100) & $42.1 \pm 1.4$ & $379.0 \pm 42.9$ \\
DLC-Ag/Si (100) & $37.4 \pm 6.7$ & $331.0 \pm 40.8$ \\
Si (100) substrate & $21.1 \pm 1.4$ & $237.0 \pm 29.7$ \\
\hline
\end{tabular}


Table 2. Composition of the phosphate-buffered saline (PBS) electrolyte.

\begin{tabular}{lcccc}
\hline & $\mathrm{NaCl}$ & $\mathrm{KCl}$ & $\mathrm{Na}_{2} \mathrm{HPO}_{4}$ & $\mathrm{KH}_{2} \mathrm{PO}_{4}$ \\
\hline Concentration $\left(\mathrm{g} / \mathrm{L} \mathrm{H} \mathrm{H}_{2} \mathrm{O}\right)$ & 8.01 & 0.20 & 1.15 & 0.20 \\
Concentration $(\mathrm{mol} / \mathrm{L} \mathrm{H} \mathrm{O})$ & $1.37 \times 10^{-1}$ & $2.68 \times 10^{-3}$ & $8.10 \times 10^{-3}$ & $1.47 \times 10^{-3}$ \\
\hline
\end{tabular}


Table 3. Relevant corrosion parameters from this study and other reports in the literature. Error ranges signify 95\% confidence intervals. All of the CPRs and some of the other values from the literature were estimated from the available data, when necessary.

\begin{tabular}{|c|c|c|c|c|c|c|c|}
\hline Authors & Material & $\mathbf{p H}$ & $\mathrm{T}\left({ }^{\circ} \mathrm{C}\right)$ & Electrolyte & $\begin{array}{c}\text { Mean } E_{\text {corr }}^{a} \\
(m V \text { vs. SCE) }\end{array}$ & $\begin{array}{c}\text { Mean } \eta_{\text {pit }}{ }^{b} \\
(\mathrm{mV})\end{array}$ & $\begin{array}{c}\text { Mean CPR } \\
(\mu \mathrm{m} / \text { year })\end{array}$ \\
\hline \multirow[t]{4}{*}{ Current Study } & Ti-6Al-4V Substrate & $7.41 \pm 0.01$ & 37 & $\mathrm{PBS}^{\mathrm{d}}$ & $-236 \pm 134$ & $--^{\mathrm{e}}$ & $0.1 \pm 0.0$ \\
\hline & Ti-6Al-4V DLC-Ag & $7.41 \pm 0.01$ & 37 & $\mathrm{PBS}^{\mathrm{d}}$ & $-77 \pm 67$ & $--^{\mathrm{e}}$ & $0.2 \pm 0.1$ \\
\hline & Ti-6Al-4V DLC-Pt & $7.41 \pm 0.01$ & 37 & $\mathrm{PBS}^{\mathrm{d}}$ & $67 \pm 35$ & $--^{\mathrm{e}}$ & $0.2 \pm 0.2$ \\
\hline & Ti-6Al-4V DLC-AgPt & $7.41 \pm 0.01$ & 37 & $\mathrm{PBS}^{\mathrm{d}}$ & $-8 \pm 42$ & $--^{\mathrm{e}}$ & $0.3 \pm 0.1$ \\
\hline \multirow[t]{2}{*}{ Oliveira et al. [69] } & Ti-6Al-4V Substrate & 5.8 & 25 & $0.5 \mathrm{M} \mathrm{NaCl}$ & -845 & $--^{\mathrm{e}}$ & $--^{f}$ \\
\hline & Ti-6Al-4V DLC & 5.8 & 25 & $0.5 \mathrm{M} \mathrm{NaCl}$ & $-345--545$ & $--^{\mathrm{e}}$ & $3.25-490$ \\
\hline \multirow{2}{*}{ Oliveira et al. [70] } & Ti-6Al-4V Substrate & 5.9 & 25 & $0.5 \mathrm{M} \mathrm{NaCl}$ & -515 & $--^{f}$ & 929 \\
\hline & Ti-6Al-4V DLC & 5.9 & 25 & $0.5 \mathrm{M} \mathrm{NaCl}$ & $-445--505$ & $--^{f}$ & $356-867$ \\
\hline Srividya et al. [71] & 301 Stainless Steel DLC & $--^{f}$ & 25 & $0.1 \mathrm{M} \mathrm{NaCl}$ & $-350--600$ & $1650-1900$ & $--^{\mathrm{f}}$ \\
\hline Feng et al. [72] & 304 Stainless Steel DLC & $--^{f}$ & 25 & $3.7 \mathrm{M} \mathrm{NaCl}$ & -125 & $--^{\mathrm{f}}$ & 0.35 \\
\hline Dorner et al. [73] & Al DLC & 7.00 & 25 & $0.6 \mathrm{M} \mathrm{NaCl}$ & -754 & 249 & 0.01 \\
\hline \multirow[t]{2}{*}{ Dorner-Reisel et al. [74] } & CoCrMo Substrate & $--^{f}$ & 25 & $0.15 \mathrm{M} \mathrm{NaCl}$ & 238 & 575 & $--^{f}$ \\
\hline & CoCrMo-DLC & $--^{\mathrm{f}}$ & 25 & $0.15 \mathrm{M} \mathrm{NaCl}$ & $69-196$ & $834-887$ & $--^{f}$ \\
\hline
\end{tabular}

a. Open-circuit corrosion potential; b. Pitting overpotential ( $\left.\mathrm{E}_{\mathrm{pit}}-\mathrm{E}_{\mathrm{corr}}\right)$; c. Corrosion-penetration rate; d. Phosphate-buffered saline; e. No pitting observed; $f$. Not reported or not investigated 
WSRC-MS-2005-00051

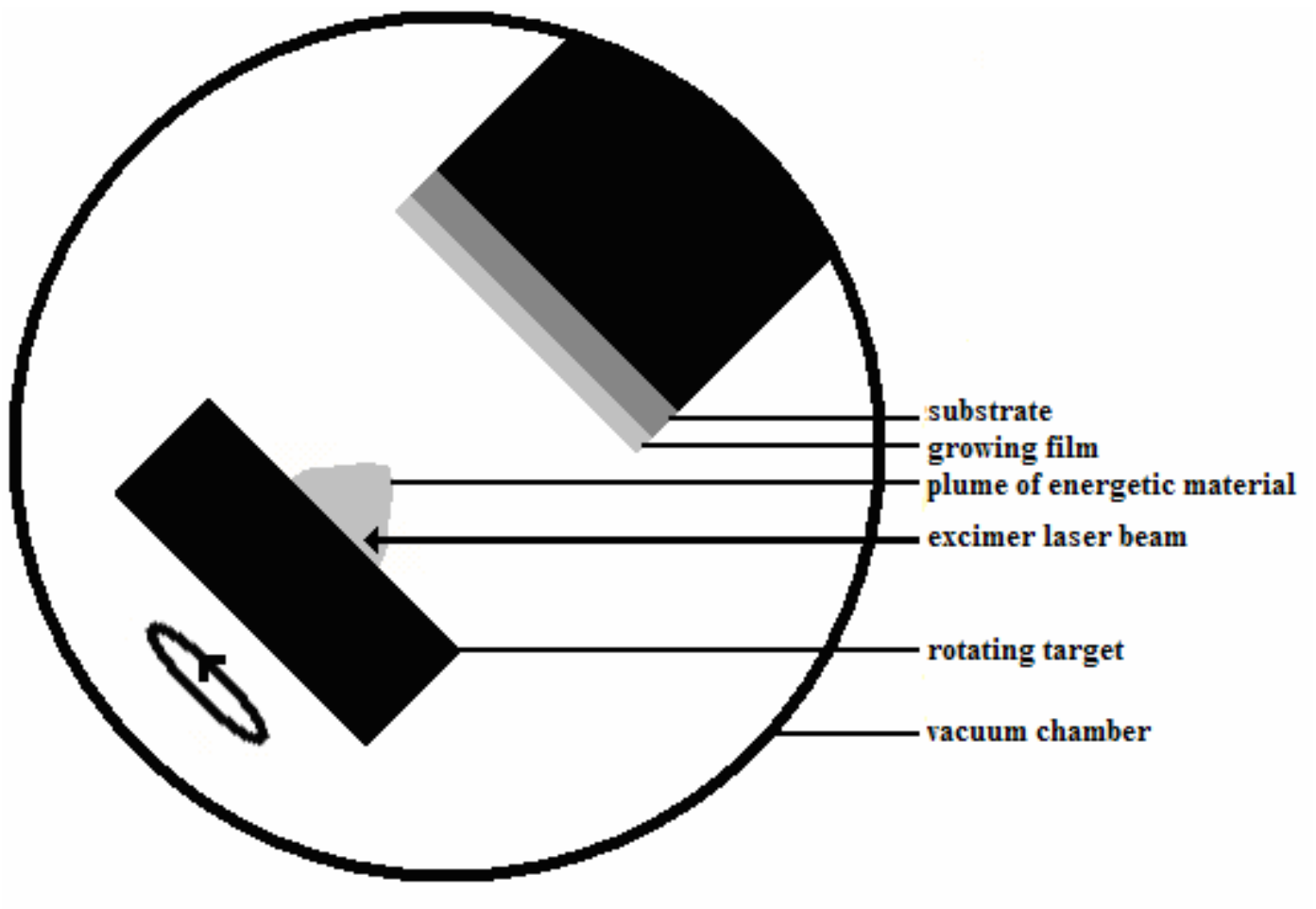

Figure 1. 


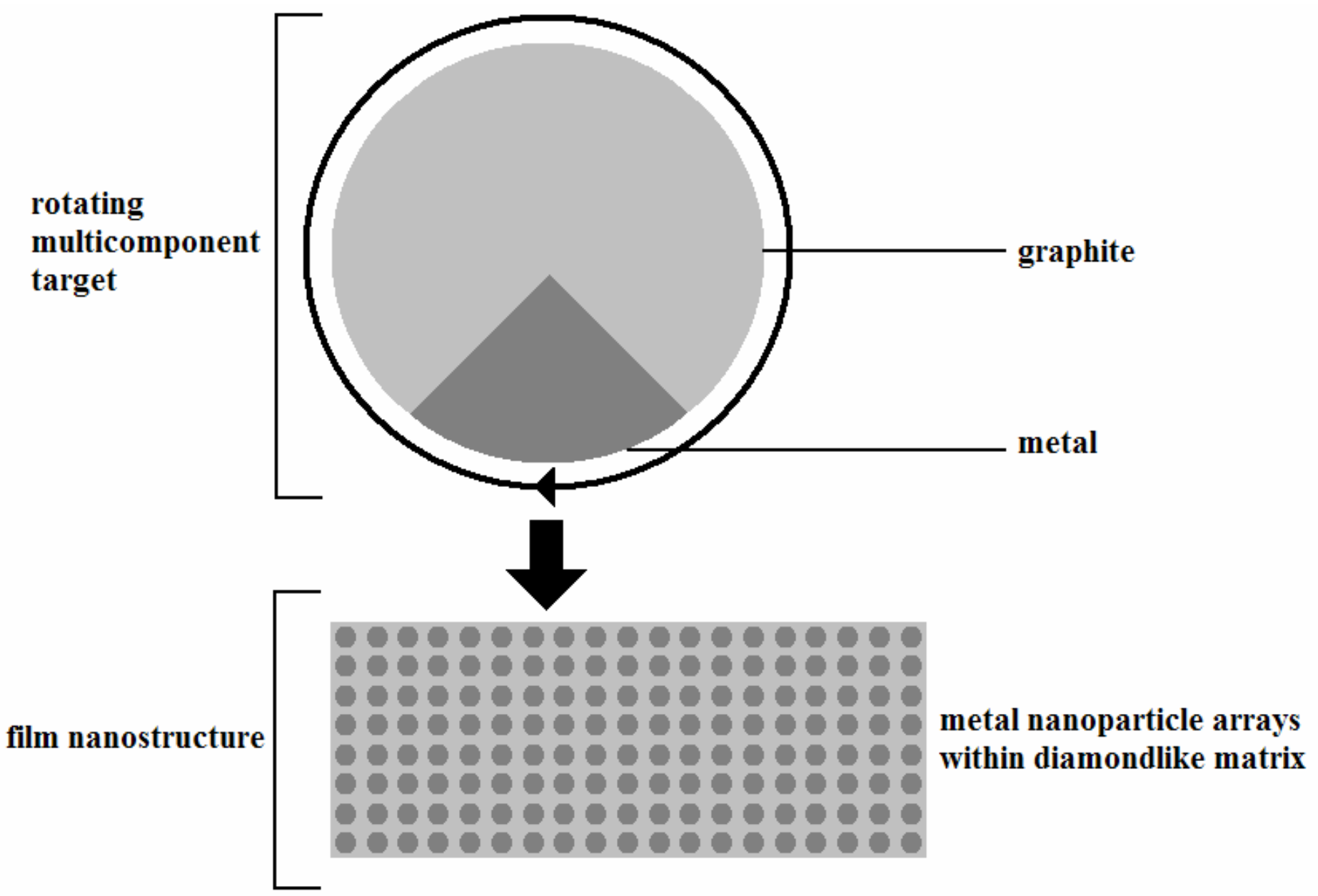

Figure 2. 
WSRC-MS-2005-00051

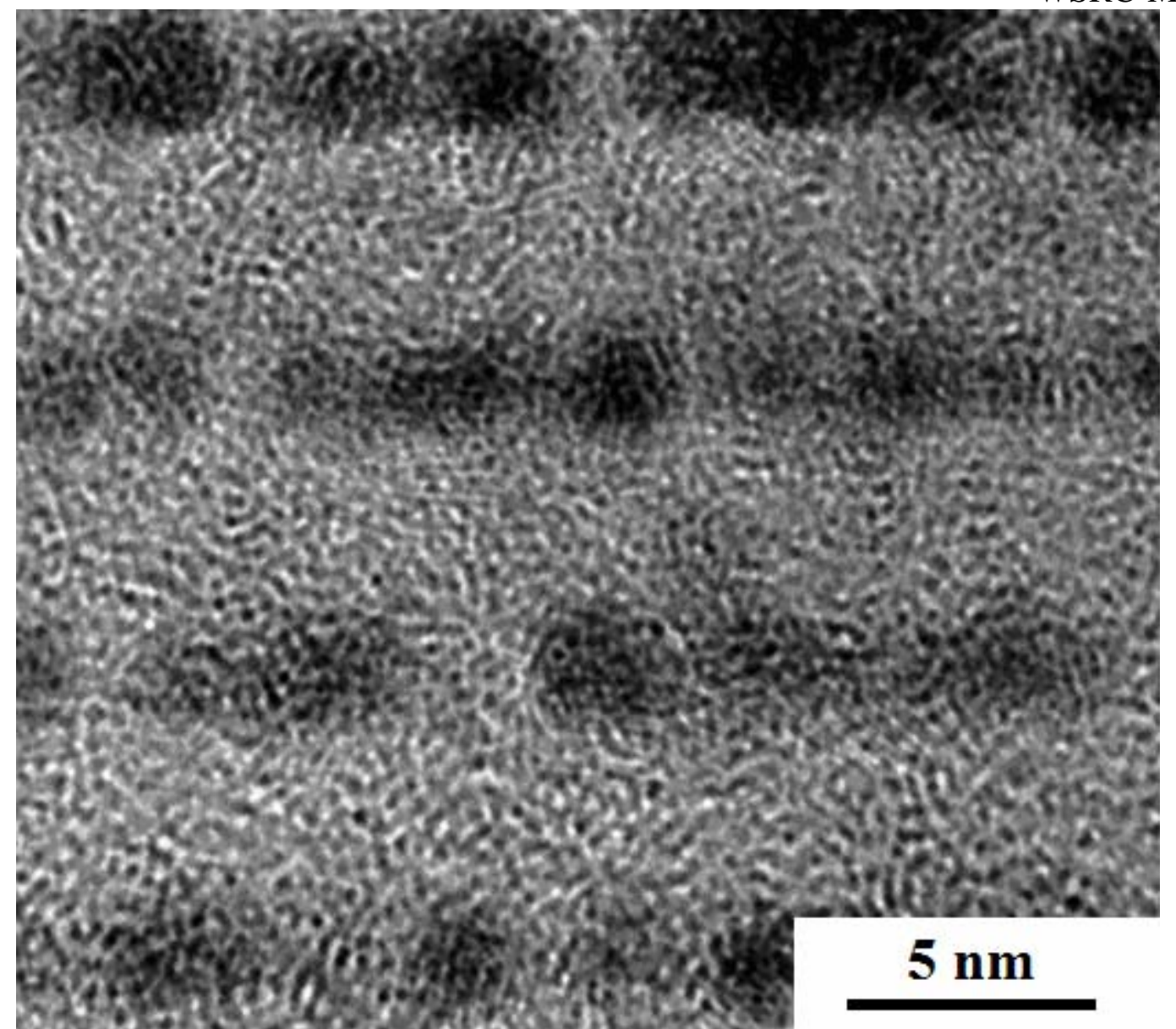

Figure 3. 
WSRC-MS-2005-00051

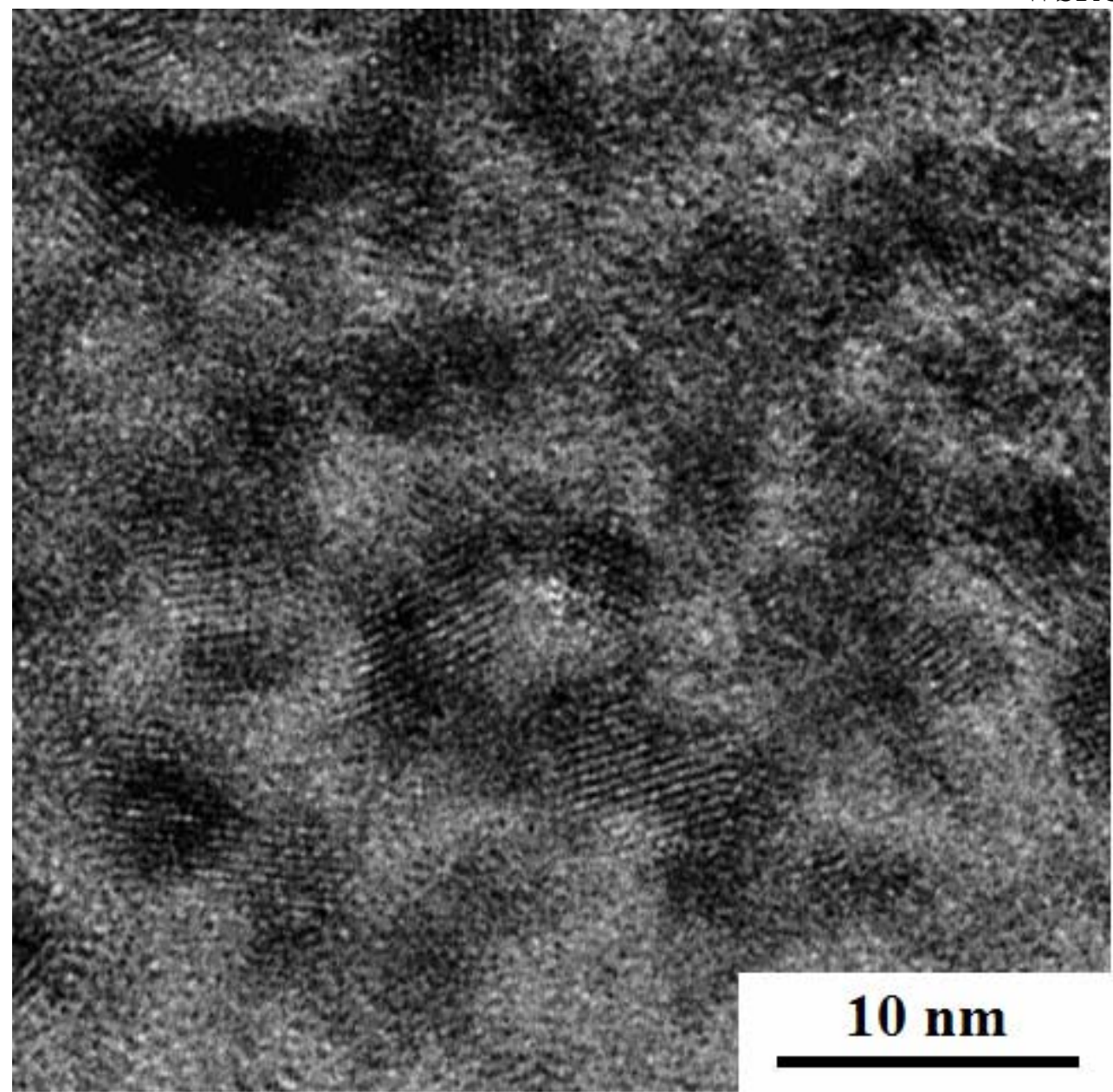

Figure 4. 

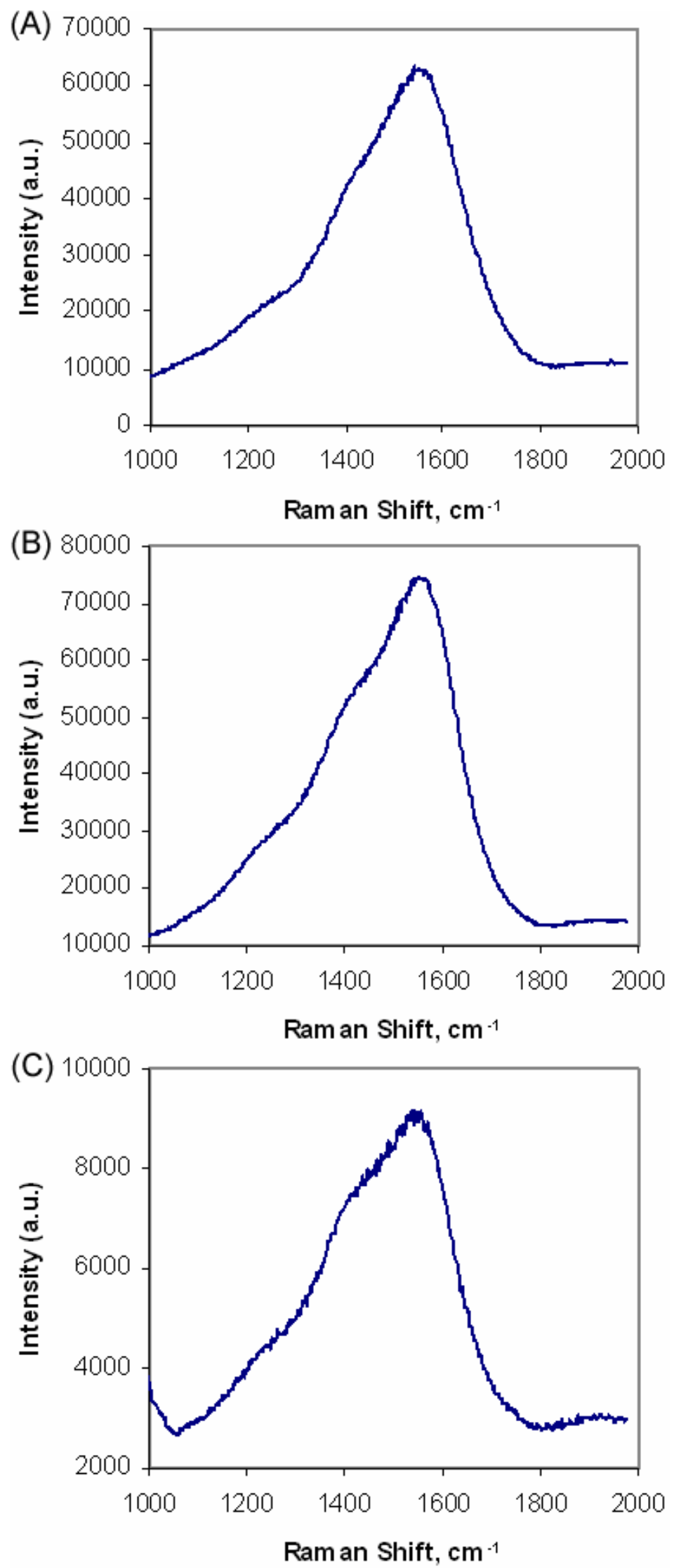

Figure 5. 


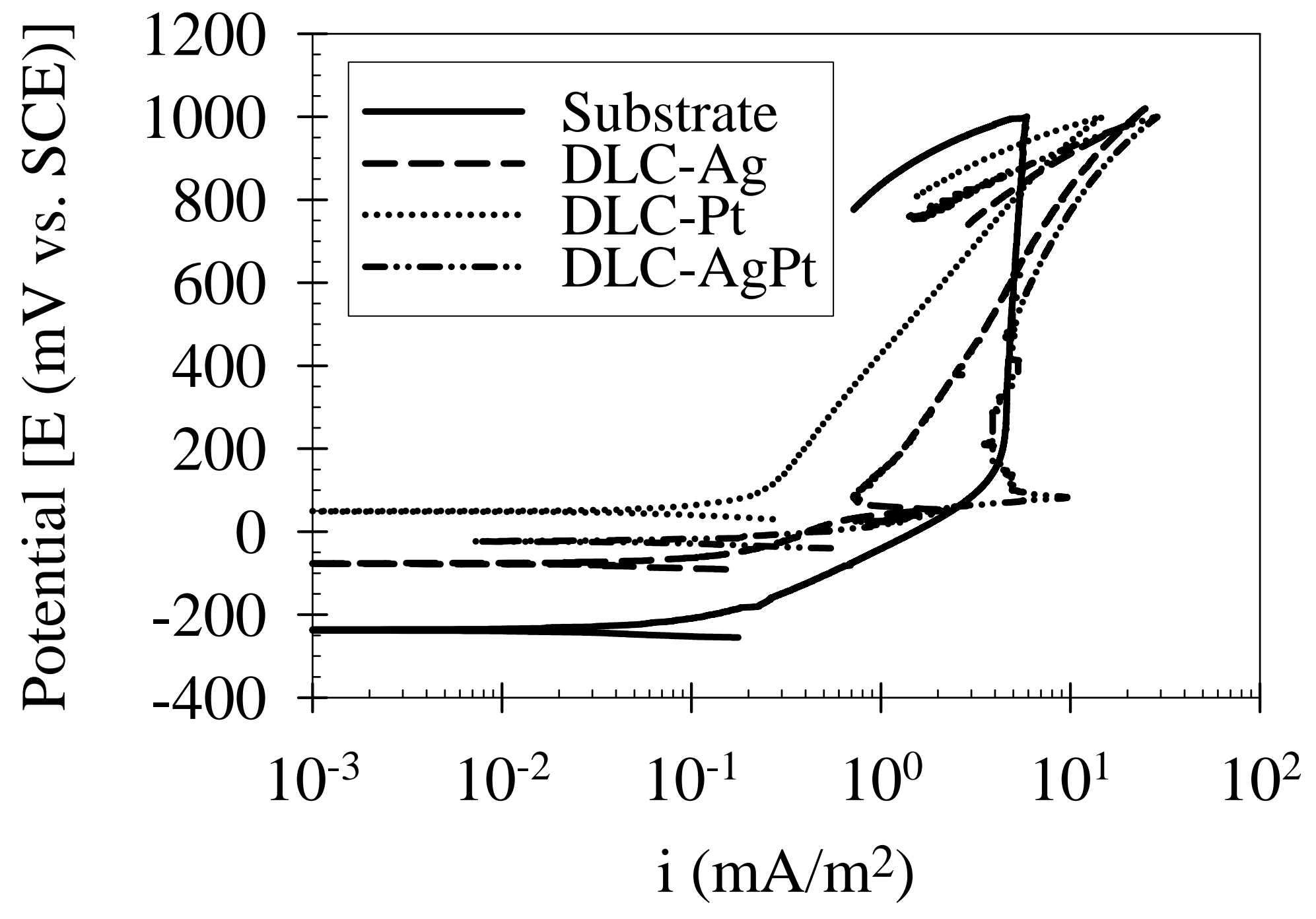

Figure 6. 


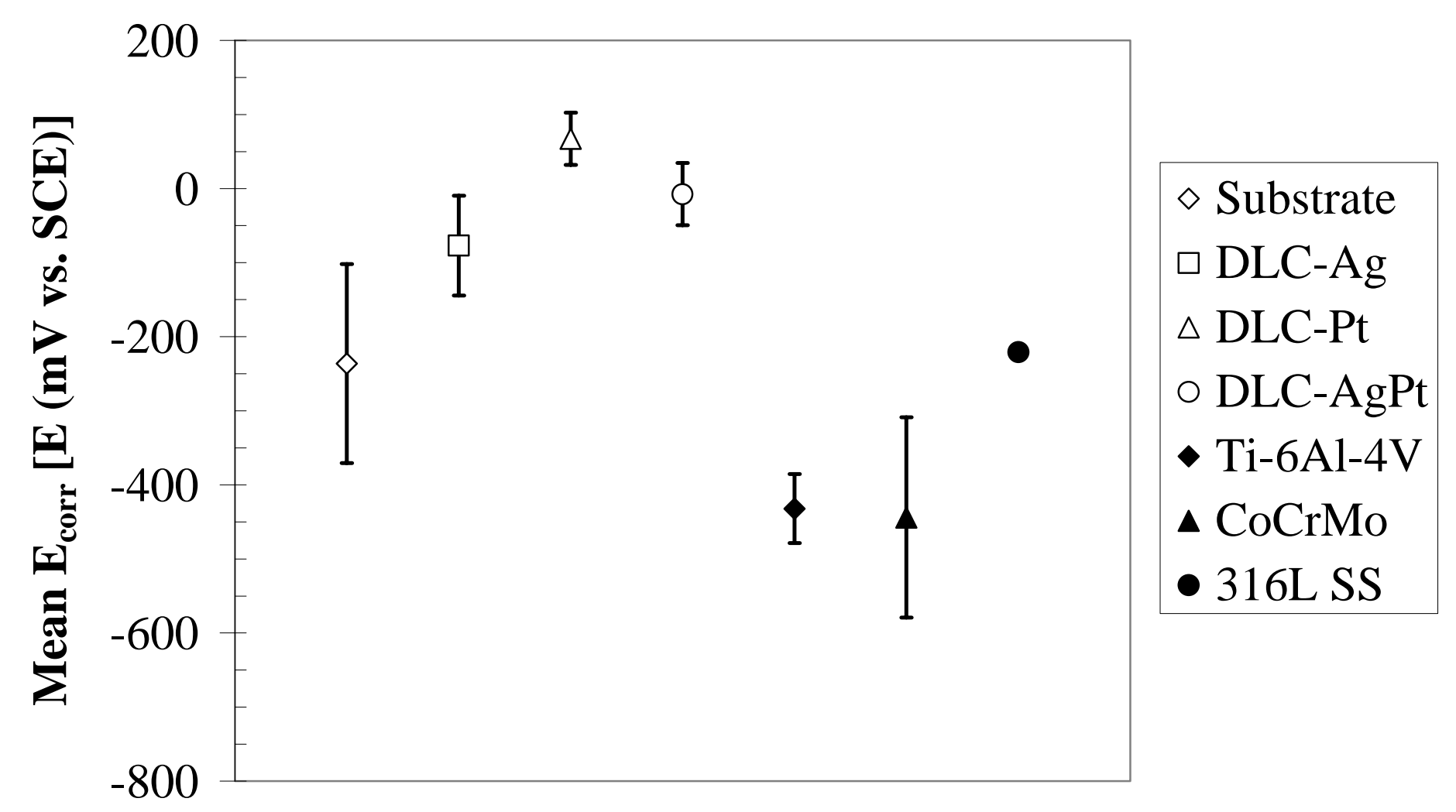

Figure 7. 


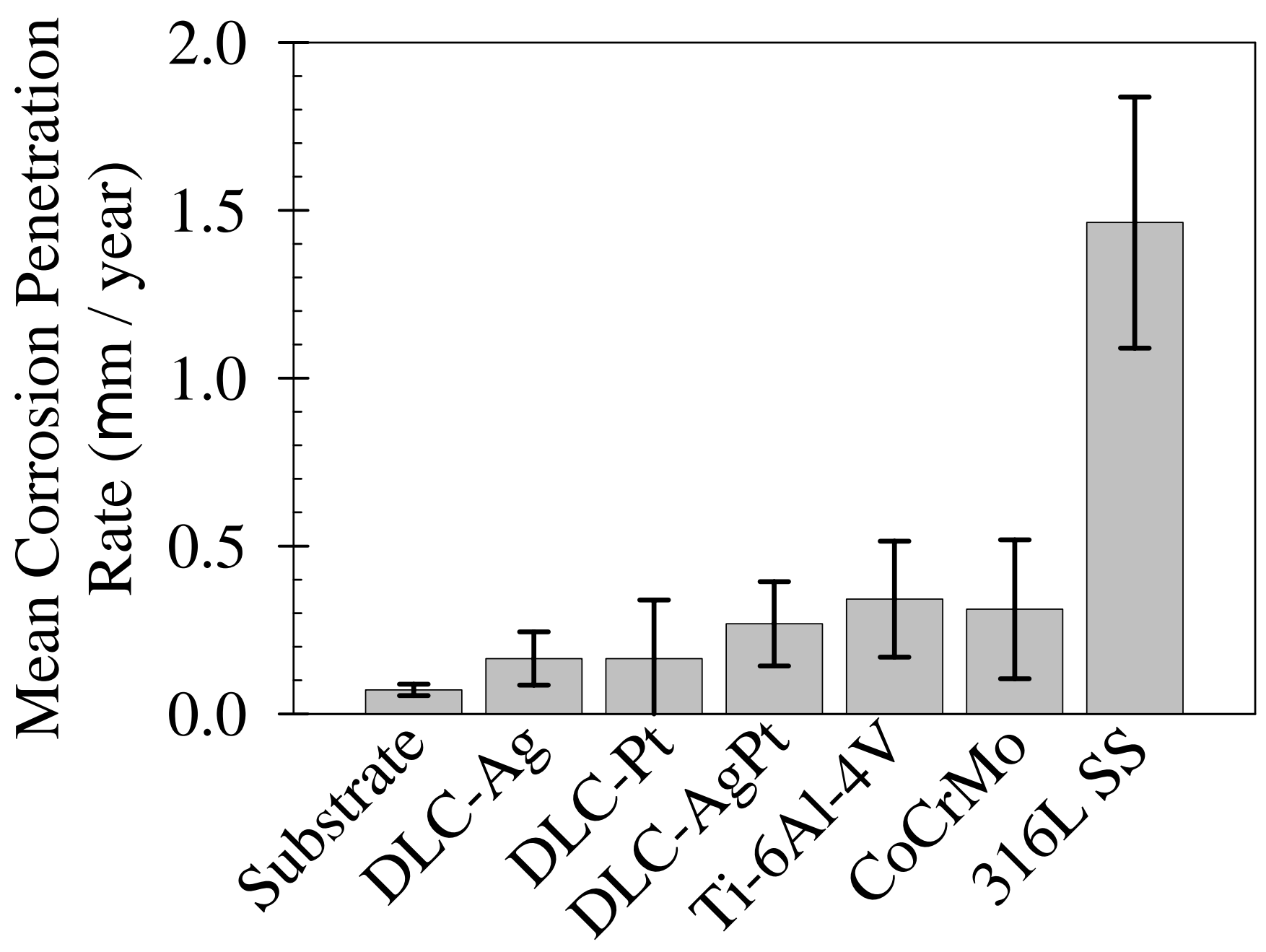

Figure 8. 

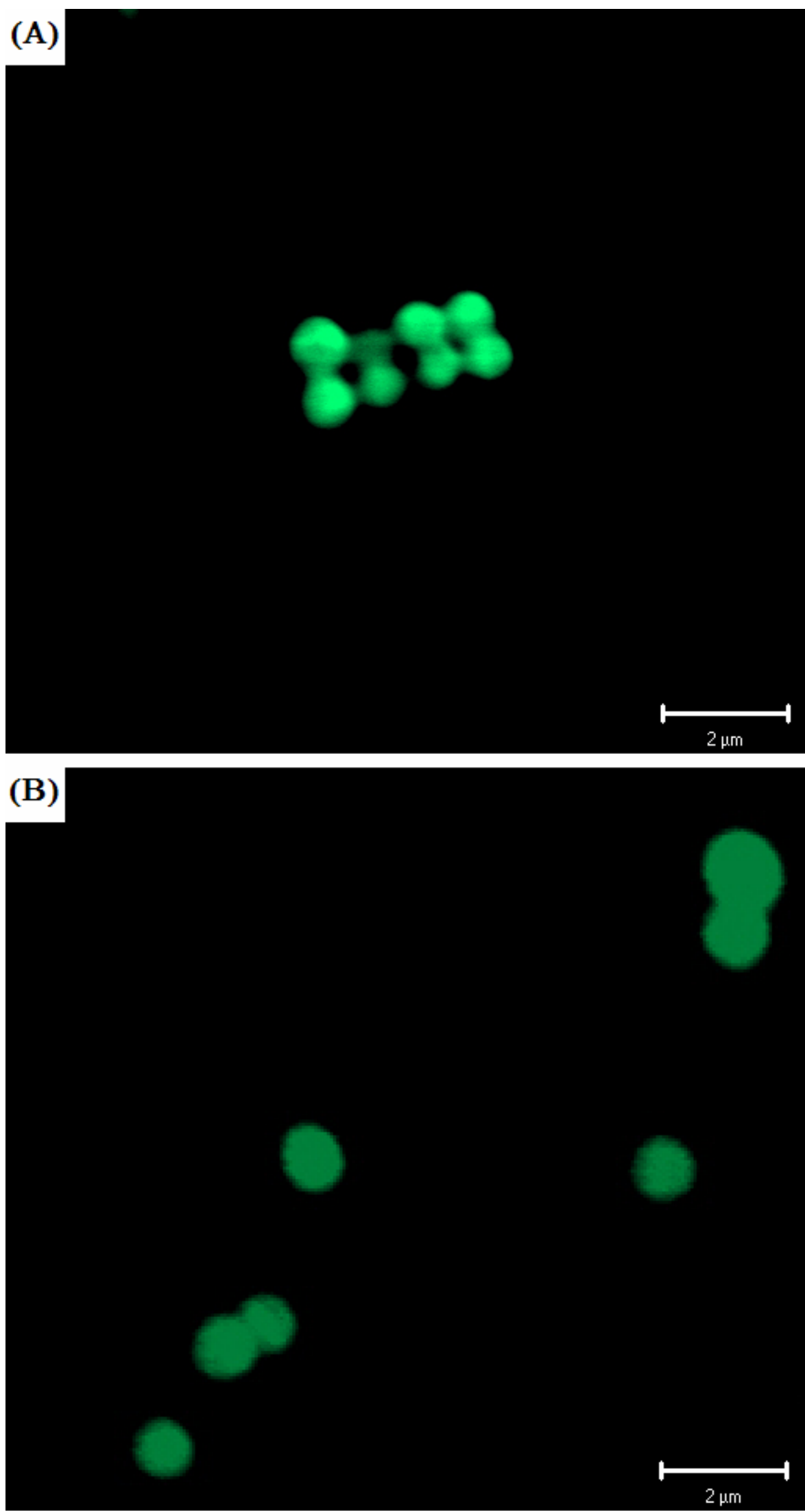

Figure 9. 